\title{
Presage: What Knowledge and Experience Higher Education Songwriting Students Bring to the Classroom
}

\author{
Diana Blom
}

University of Western Sydney

d.blom@uws.edu.au

Kim Poole

Korowal School, Sydney

kpoole@korowal.nsw.edu.au

\begin{abstract}
This study analyses the responses of seventy-six students from three Australian higher education institutions in New South Wales entering the songwriting classroom for the first time. While it was assumed that most students had previously composed songs, their views on, and experience with, a range of issues relevant to songwriting itself were unknown. Through a questionnaire seeking responses about student songwriting experience and process, lives in relation to lyrics, inspiration and compulsiveness, notation theory and craft, songwriting order and sense of completion, and notions of "audience" and "market", findings about the songwriting skills and knowledge students bring to the classroom in the presage stage are discussed. This is then related to a model of previously acquired skills.
\end{abstract}

KEYWORDS: songwriting, higher education students, presage, skills acquisition, inspiration, notation 


\section{Introduction}

There is a limited quantity of existing research into songwriting in the music education environment. Examples include a focus on original music-making, cooperative learning and sociomusical relationships (McGillen and McMillan 2003, 2005) and songwriting as a group (McGillen 2004) at secondary level; developing creativity in pre-service teachers (Kennedy 2004); and two pdf papers on the web, at the time of press, one unnamed, discussing principles for teaching and assessing songwriting in higher education (Unknown 2004) and creating an MA in songwriting (West n.d.). Yet, "what students can learn depends, to a larger extent than previously assumed, on what they already know" (Barkley et al. 2005: 12) and what students already know and bring to the classroom is "presage". Dictionary definitions of "presage" carry a feeling of something unknown about to happen, the "foreshadow[ing of] a future event" (Macquarie 1999: 619) and it is this unknown foreshadowing to which this paper responds, through the research question of what knowledge and experience about songwriting higher education students bring to the songwriting learning environment. This study analyses the responses of students from three Australian higher education institutions in New South Wales. While it was understood that most of these students had previously composed songs, their views on, and experience with, a range of issues relevant to songwriting itself were unknown. Findings about the songwriting skills and knowledge students bring to the classroom in the presage stage are discussed, and related to a model of previously acquired skills.

\section{Presage and skill acquisition}

There has been a rise in interest in the views of students in relation to their own learning. For the student, "it is easier to learn something when we already have some background than it is to learn something complete new and unfamiliar [... as] what one knows about a given subject has a substantial impact on the learning process" (Barkley et al. 2005: 12). In Biggs' (1989: 12) model of learning, Student Characteristics of "abilities, motivation, conception of learning" combined with "Teaching Context" (curriculum, method, assessment, climate) make up the first of three integrated stages - presage, process, product. "Presage factors exist prior to learning, and relate to the student, and to the teaching context. Students come to university with certain abilities, expectations and motivations for learning".

Less attention has been paid to presage factors than to those of the process and products of a learning system (Lebler et al. 2009). Lebler, Burt-Perkins and Carey's study focused on prior learning of undergraduate students in a UK tertiary music conservatoire and two Australian bachelor of music programs, one with a western classical focus, one with a popular music focus, including "students" hopes, fears and expectations" (ibid.: 233) musically, academically and socially, the kinds of music they have studied, private lessons and other ways of learning music, styles of feedback used in this learning and what music-making activities they engage with.

Within presage there may be a range of experiences and understandings. Dreyfus' (1982) five-stage model of human skill acquisition process is discussed in 
relation to business expertise, referring also to chess playing (deGroot 1965), acquiring improvisatory jazz ability (Sudnow 2001) and acceptable scientific practice (Kuhn 1970). Benner (1984: 13) drew the model into clinical nursing practice noting three observable aspects of skilled performance: "a movement from reliance on abstract principles to the use of past concrete experience as paradigms"; the learner sees the situation "less and less as a compilation of equally relevant bits, and more and more as a complete whole in which only certain parts are relevant"; and the student progresses from "detached observer to involved performer [...] no longer stand[ing] outside the situation but [...] now engaged in the situation" (ibid.). In "Novice", the beginner begins by "decomposing the task environment into objective attributes which [...he/she...] can recognize without benefit of experience" (Dreyfus 1982: 141), with "rules to guide their performance" (Benner 1984: 21). "Advanced beginner" shows "marginally acceptable performance [...which] comes only after on-the-job coping with real situations in which the performer notes [or teacher illustrates] recurrent meaningful situational component patterns" (Dreyfus 1982: 141). "Competence" sees the performer recognising and becoming consciously aware of the relevance of a whole situation to a long-term goal (Dreyfus 1982). This "ends-in-view that the learner forms during the process of learning" (Westerlund 2008: 87) ideally sees learning being "integrated into the stream of experiences that carry their voice throughout the learner's life, becoming part of his or her selfconstruction" (ibid.: 90). In "Proficiency", the performer has such a wide experience of different situations, "a sense has unconsciously developed for the best plan in such a situation" (Dreyfus 1982: 144) with situations perceived as a whole (Benner 1984). For Dreyfus (1982: 146), "Expertise" is when the expert performer "immediately dictates an intuitively appropriate response" because of an acquired repertoire of experienced situations. The expert experiences "moments of intense absorption in his work, during which his performance transcends even its usual high level" (Dreyfus and Dreyfus 1980: 14) and "reflection has [...] become an unconscious process" (Butler 1996: 279). In fact, "reflection is the process that propels people along the journey from novice to expert" (ibid.). The model Dreyfus provides will be discussed further in the conclusion of this paper, and applied to songwriting based on our evaluation of the approaches of a number of student songwriters.

\section{Songwriting}

Frith (1987) suggests music aids (amongst other things) in creating the identity of the individual, opens an avenue of expression that organises our public and private lives, and shapes our memory. For many songwriters these connections are an integral part of their inspiration and craft (Zollo 1997) and from interviews there emerges a strong connection between the self and the song, a deeply personal activity exploring one's inner world. Jackson Browne (in Hoskyns 2005: 167) believes that "the process of writing a song is really the process of confronting something internal". Life events, recent and long ago, can become topics for song lyrics. Writing songs after a recent marriage break-up, Suzanne Vega (in Lowman 2001: 4) found herself confronted with feelings from years 
before: "You could have sworn they were dead and buried, and then they pop up again demanding to be looked at".

For many, songwriting is a compulsive activity filling an individual personal and musical need, "the truth is that both singing and writing are informed by the fundamental need of singers and writers to do it: singers need to sing, perform or write songs, a process that is essentially one of self-revelation" (Potter 1994: 198). Dolly Parton believes "you have to have that gift and that burning desire" (in DeMain 2004: 38). For some the muse needs to be fed. Elvis Costello and Tom Petty admitted to Flanagan (1987: xiv), "they had deliberately played havoc with their personal lives and with the lives of the people around them in order to keep the music coming".

Some songwriters deny any link between their songs and their life, but they cannot control what interpretation the listener will give to the song. Despite Van Morrison's "oft-avowed conviction that Life and Work are wholly distinct" (Mills 1994: 91), Mills finds the singer's songs to be as "autobiographically succinct as the more poetically charged material relating to memory" (ibid.: 102).

Many professional songwriters explore personal issues in masked or coded ways, utilising third-person narratives or obscuring details to render the songs less specific. Writing in first-person narratives, Joan Armatrading (in Flanagan 1987: 425) argues that while she draws on autobiographical issues in her songs, most are about different people; she tries to see what they are going through and writes all her songs "as if they were personal". While remaining concerned with personal issues, Neil Young (in Flanagan 1987: 123) deliberately hides the meanings of lyrics to obscure the identities of those concerned so that "nobody gets to nail you for it". Joni Mitchell, in contrast, is renowned for the transparency of her songwriting, particularly those on the landmark album, Blue. James Taylor (in Hoskyns 2005: 125), who was conducting an affair with Mitchell at the time she was writing the album's songs, noted: "everyone who writes songs writes autobiographical songs. But hers are sometimes alarmingly specific".

A smaller number of professional songwriters have expressed an interest in writing about wider, social contexts and historical events. Sting (in Flanagan 1987) describes songwriting as part of a long tradition going back to the troubadours, where songs gave information to the people. He thinks songs, at their best, can still impart news in an entertaining and informative way. Tori Amos (in DeMain 2004: 158) concurs: "We are documenting a time [...]. Music can do that in a way that nothing else can".

Expressing one's individual personal experiences in, and social acceptance through, songwriting was the aim of an upper primary level teacher who teamed a local folk musician with six classes of sixth grade general music to create a folk song (any popular music style) that represented their experiences as sixth graders in their middle school (Kaschub 1997). In music therapy, song writing offers clients a way of expressing personal journeys, events and feelings through, what can become, an empowering process (Hadley 1996, O'Callaghan 2004).

Inspiration has been defined as "that which causes, provokes, forces the artist to create - the catalyst of the creative process" (Harvey 1999: ix). For Harvey (ibid.: 5), it "activates and brings to light areas of the psyche that are normally deeply obscure, and it is frequently an overwhelming, ecstatic experience", often so intense composers may find it difficult to understand that it is coming from 
themselves. Discussing the songs on the CD Modern Times, Bob Dylan (in Lethem 2006: 50) located inspiration in a state of mind that derived from his physical being: "I wrote these songs in not a meditative state at all, but more like in a trance-like, hypnotic state. This is how I feel? Why do I feel like that? And who's the me that feels this way? [...] Those songs are just in my genes and I couldn't stop them comin' out". There is often a spiritual if not religious aspect to the responses of professional songwriters when asked about the songwriting process. For Keith Richards (in Flanagan 1987: xiii), songs "arrive at your doorstep and all you do is give them an airing, make it possible for them to exist"; and Bono (ibid.: xii ) "feel[s] like the songs are already written". Some songwriters believe the inspirational flow requires readiness on the part of the receiver. Charles John Quarto (in Gillette 1995: 100-101) says "I sit down when I have that feeling".

There are several textbooks about the techniques and processes of songwriting focused on writing song lyrics (Citron 2000; Davis 1985 and 1992; Pattison 1995), musical parameters including rhythm, structure, harmony and melody (Citron 2000; Josefs 1996), and the production or business aspect (Blume 1999). There are also several books in which songwriters are interviewed about their songwriting process (DeMain 2004; Flanagan 1987; Kruger 2005; Zollo 1997). Significantly, fewer professional songwriters have been prepared to discuss the songwriting process in terms other than inspirational, although Jimmy Webb (1998) is an exception. Whether this is hubris, secrecy, or a lack of terminology is difficult to say. Lilliestam (1996: 208) notes there are many accounts of how rock songs have originated, but most deal with lyrics and inspiration, and quotes Paul Simon, interviewed by Flanagan (1990, xi), as saying that "When people write about song writing they tend to write about lyric writing. It's very hard to write about music. What do you say about it? Music is a nonverbal experience. It's easier to address words. [...] The music part of song writing is much more potent and powerful than the lyric part. But it's harder to write about". However when songwriters are questioned directly about how they write songs, as DeMain (2004) and Kruger (2005) did, most addressed issues of lyrics and inspiration, but many also talked of such musical parameters as melody, harmony, riffs, hooks, and instruments and recording technologies as tools for shaping musical ideas. Certainly those who have been prepared to discuss the craft of shaping a song tend to be songwriters, such as Elvis Costello, who have actively pursued a formal musical training. Some songwriters have acknowledged the role of craft to shape "inspiration" into a song-product. Paul Simon and James Taylor, for example, believe there is a burst of much appreciated inspiration, but then hard work "to beat the mystical protoplasm into shape" (Flanagan 1987: xii).

"The physicality of playing music [...] can be the 'source' or stimulus of a new song and thereby new understanding" (Carless and Douglas 2009: 34). Dolly Parton (in DeMain 2004: 32) can start songwriting from the impetus of her guitar. She might have an idea, pick up her guitar, "hit a lick here just to hear the sound of music [and] sometimes it sounds really good [...] I'll just start playing and I'll just start singing some words and all of a sudden something will pop out, then before I know it, I've started a song". Some songwriters shift between two (or more) instruments because they feel the different idioms serve the process in different ways. Daniel Jones of Savage Garden (in Kruger 2005: 554) uses a piano "for the melodic side of things" and a guitar "for the rhythmic side". Teenagers 
Matt (McGillen 2004) and Michael talk of group jamming to create group compositions, starting with a riff or pattern from the guitarist, words from the lead singer, then "they'Il, come up with sort of the basic bits of the song and then the structure is more down to me" (Green 2001: 81).

A few songwriters prefer to limit their reliance on instruments. Burt Bacharach (in DeMain 2004: 3-4) likes to work away from the piano as soon as possible so that he is not concerned about what his fingers and hands are playing and also because his hands often lead him to where they've been before. Off the piano, he can hear the whole song evolve instead of getting "trapped by pretty chords". Moving from a familiar instrument to one less familiar can also be a strong song writing impetus. Sarah McLachlan (in DeMain 2004: 173) does not have a piano and usually works with a guitar so working with a piano "was such an exciting thing, a new sound, a new instrument. That happened with electric guitar as well".

Creating a harmonic progression provides an initial step in the songwriting process. Archie Roach (in Kruger 2005: 532) says "Took the Children Away", his best-known song, began with a chord progression that accompanied the title phrase: "I had the idea there, and then I went home and I sat down and I started strumming a few chords. Three chords. Just a chord succession". For many songwriters, the studio and/or recording technologies are their "instrument" and an integral and flexible part of the song writing process. Lindsey Buckingham (in DeMain 2004: 101) of Fleetwood Mac tends to use recording technologies to replace what he perceives as a lack of traditional knowledge. When he composes he might begin with "fragments or ideas that are not particularly well fleshed out" and then uses the tape machine as a canvas and "start[s] to work the painting [...] so the actual record-making side of it affects to a great degree the writing and vice versa".

Some songwriters find the process of writing the song continues through the arranging and recording process. Once Daniel Jones (in Kruger 2005: 556) has written something organically on the guitar or the piano he can turn to "technology to enhance that [...] it's just a fact of song writing now". Todd Rundgren's (in DeMain 2004: 90) advice for songwriters is "to take more time. [...] In a sense, you could say, it's never done. There's always room for improvement".

A prevalent ideology amongst songwriters, both those with formal music theory training and those without (and the continuum between), concerns the notion that an understanding of music theory hinders creative freedom. Amy Grant (in DeMain 2004: 136) was told that "music can lose its magic" with a welldeveloped music theory knowledge: "If I were you, I would celebrate your limitations". Pre-service teachers, in a US tertiary institution, undertaking a songwriting composition task, frequently commented on their prior music training, skills and knowledge as both enabling and constraining. For several, the years of formal theoretical training seemed to hamper their freedom of approach (Kennedy 2004). At secondary level, Matt, says "I think it actually adds not having music, 'cos you can write down notes but you can't write down the spirit of the songs" (McGillen and McMillan 2003: 45). Even Burt Bacharach (in DeMain 2004: 3), from a position of extensive schooling in the principles of European composition, concedes that theory "rules" need to be overcome: "all the technical 
study [...] it's all very helpful. [...] To read and to be able to write music. I think you learn the rules so you kind of break the rules".

TABLE 1: Questions posed in the questionnaire and their sources.

\begin{tabular}{|c|c|}
\hline 1 & How many songs have you written? \\
\hline 2 & $\begin{array}{l}\text { How compulsive (if at all) an activity is songwriting in your life? (Folds in } \\
\text { DeMain 2004; Nathan in Campbell 1998; Parton in DeMain 2004; Potter } \\
\text { 1994) }\end{array}$ \\
\hline 3 & $\begin{array}{l}\text { What role/purpose does songwriting play in your life? (Browne in Hoskyns } \\
\text { 2005; Frith 1987; Potter 1994) }\end{array}$ \\
\hline 4 & $\begin{array}{l}\text { How would you characterise your song lyrics? For example, are they } \\
\text { predominantly: } \\
\text { - an exploration of your internal world; (Kaschub 1997; Mills 1994; Vega } \\
\text { in Lowman 2001; personal observation after marking songs) or } \\
\text { - an exploration of a series of topics/subjects? (Amos in DeMain 2004; } \\
\text { Sting in Flanagan 1987) }\end{array}$ \\
\hline 5 & $\begin{array}{l}\text { When you write songs do you aim for lyrics which have a specific } \\
\text { meaning or lyrics which are open to interpretation? Why? (Armatrading in } \\
\text { Flanagan 1987; Young in Flanagan 1987) }\end{array}$ \\
\hline 6 & $\begin{array}{l}\text { If various elements occur simultaneously (that is, words and melody } \\
\text { together) is this an example of inspiration? (Dylan in Letham 2006; Harvey } \\
\text { 1999) }\end{array}$ \\
\hline 7 & $\begin{array}{l}\text { How would you characterize the balance of inspiration and craft in your } \\
\text { songwriting process? (DeMain 2004; Kruger 2005) }\end{array}$ \\
\hline 8 & $\begin{array}{l}\text { What is your preferred order of songwriting process? (lyrics then melody } \\
\text { then harmony, etc.). Why do you prefer this order of process? (Michael in } \\
\text { Green 2001; Parton in DeMain 2004; Roach in Kruger 2005) }\end{array}$ \\
\hline 9 & When do you feel a song is complete? (Rundgren in DeMain 2004) \\
\hline 10 & $\begin{array}{l}\text { Once a song is complete do you continue to edit and develop it? If so, } \\
\text { describe this process (Jones in Kruger 2005) }\end{array}$ \\
\hline 11 & $\begin{array}{l}\text { How does your level of music theory knowledge restrict, assist or } \\
\text { empower your process? (Bacharach in DeMain 2004; Grant in DeMain } \\
\text { 2004; Green 2001; Santana in DeMain 2004) }\end{array}$ \\
\hline 12 & $\begin{array}{l}\text { Is your songwriting geared to a particular market? If so, how does this } \\
\text { impact on your songwriting craft? (Berry in Flanagan 1987; Keil 1985; } \\
\text { McDonald in DeMain 2004; Piggott in Kruger 2005; 1982) }\end{array}$ \\
\hline 13 & $\begin{array}{l}\text { How important is the role of an audience to your songwriting? (Söderman } \\
\text { and Folkestad 2004) }\end{array}$ \\
\hline 14 & Ings and w \\
\hline
\end{tabular}

Green (2001) finds that notation is not used for preserving or passing music on but plays some roles in the performing process, with music which is read being internalised and becoming part of the aural process. For teenage musicians, a combination of aural and notated composing is typical. A teenage rock musician stated that the notated aspect of songwriting consists of "putting down words, and 
the chords above them" (Campbell 1995: 18) with melody and accompaniment all composed orally. Carlos Santana (in DeMain 2004: 76) sees benefits of working by ear and with notation (if the songwriter has the facility and knowledge) but sides more closely with an aural approach: "If you see it, you paint it. If you hear it, you play it [...]. Now, if you have both, like Wayne Shorter, who can see it and hear it and read it, then you got something else [...]. But it's not essential".

In many popular music subcultures the artist and their audience are held to be interchangeable. Notions of style are implicated here because style (musical or otherwise) can function as an indicator of subcultural groups. Style represents "a deeply satisfying distillation of the way a very well integrated human group likes to do things" (Keil 1985: 122). Concepts of market typically implicate production and product and are intimately associated with industrial capitalism. Markets, in this context, are seen as "mechanisms for social control" involving "the production and consumption of material symbolic goods" (Shepherd 1982: 149150). An audience group, bonded by musical style affinities, may represent a market for the production and consumption of material goods but it exists ideologically at considerable remove.

One powerful ideology associated with many popular music subcultures is the notion that creative efforts aimed at reaching mainstream markets are inauthentic because they aspire to commercial success. Johanna Piggott (in Kruger 2005: 462), whose musical background was in art/punk rock, found she had to let go of this ideology when she began to achieve wider success with her songwriting: "The thing I had to give up was that artistic, precious, groovy thing and write a commercial song [...]. There is absolute validity in writing commercial nonintellectual entertainment". The members of one of the groups in Söderman and Folkestad's (2004: 317) study of hip-hop musicians were from Ghana, Lebanon and Switzerland, and felt it was important to be commercial and be able to earn a future income in hip-hop rather than viewing themselves as members of an idealistic, underground hip-hop movement. For them, "entertainment was more important than the political message [...yet] their personal image and identities were important and the lyrics were often aimed at bringing these out". American songwriter, Michael McDonald (in DeMain 2004), advises against aiming for a specific market while, in contrast, Chuck Berry (in Flanagan 1987: 80) writes songs for his livelihood, because that's how he earns his living: "I will write whatever I think is going to sell to the most people".

\section{Methodology}

We sought a methodology which could draw out information about songwriting and personal identity, the role of inspiration in songwriting and its process, student thinking about music notation and songwriting, plus their thinking on aspects of style, audiences and markets. In order to give participants time, and distance from teaching staff, to reflect on the questions, a questionnaire was selected as the most suitable data-gathering tool. Three classes of tertiary student songwriters were asked to respond to a questionnaire enquiring into their songwriting experience and knowledge. The three different higher education 
institutions in New South Wales were a city-based university (CBU) which offered study in popular and classical musics, and songwriting complemented classical composition study; a regional university (RU) offering a music program dedicated to contemporary popular music and its industry, with song-writing a core unit for all students; and a regional technical and further education institute (TAFE), with a vocational training mission also focused on the contemporary popular music industry. Despite students at RU and TAFE being in their first year of study and those at CBU in their second year, all were studying songwriting for the first time. The teaching focus was largely notation-based with the RU students recording/arranging their songs. While the songwriting teachers at the three institutions were all experienced composers, this was largely in the classical and ethnomusicology/folk realm. However, some had experience with different areas of popular music: as "a recreational songwriter" (CBU), "songs in bands and for popular music theatre productions" (RU), and "cabaret and music theatre experience" (TAFE; Hannon and Blom 2012: 57). Teaching was undertaken through lectures, workshops, peer and teacher feedback with collaborative songwriting submissions accepted at the RU and TAFE (ibid.: 7). Seventy-six undergraduate students from the three institutions responded to the questionnaire, seventeen at $\mathrm{CBU}$, twenty-four from TAFE and thirty-five from RU. Gender identification was not requested.

Question style in the questionnaire ranged from those requiring a one-word response, those seeking a short narrative, to some requiring both, with question topics drawn from the literature and from our own observations and experiences (see TABLE 1). Responses were sought on students' songwriting experience and process; their lives in relation to lyrics, inspiration and compulsiveness; notation theory and craft; song-writing order and sense of completion; and notions of "audience" and "market" as they impacted on song-writing. Many students responded fulsomely to all questions, regardless of the questioning style.

All questions, except No. 14 which was beyond the focus of this paper, were analysed, beginning with coding and counting made in relation to the questions being asked. When a response covered two coded topics, both were counted and are included in the percentages. This deductive approach was complemented with a more inductive constant comparison strategy whereby, as topics and codes were encountered, recorded and classified, they were also "compared across categories [...allowing] continuous refinement throughout the data collection and analysis process" and the discovery of new relationships (LeCompte and Preissle, 1993: 256).

\section{Findings}

We wanted to know how many songs the students had written to gauge their experience with songwriting. The majority had been writing songs before entering the songwriting courses in the three institutions (TABLE 2). Songwriting is a reasonably compulsive activity in the lives of students, in a majority of responses $(81 \%$; TABLE 3$)$. On the surface, the question was about time spent, and the urgency of, songwriting yet responses drew out other issues. Songwriting could be a constant activity, though not necessarily a compulsive one; it could be 
compulsive yet sporadic, undertaken when the mood or inspiration strikes. Students wrote of songwriting as a way of expressing personal issues and therefore a major requirement in their lives. For others, by themselves, songwriting is "generally something that just happens when I play."

TABLE 2: Number of songs written before entering the songwriting classroom.

\begin{tabular}{|l|l|}
\hline CODE & TOTAL \\
\hline None & 1 \\
\hline 1 & 0 \\
\hline $2-3$ & 7 \\
\hline $4-10$ & 28 \\
\hline $11-29$ & 16 \\
\hline 30 and over & 24 \\
\hline
\end{tabular}

TABLE 3: The compulsiveness (if at all) of songwriting in students' lives.

\begin{tabular}{|l|l|}
\hline CODE & TOTAL \\
\hline Very & 27 \\
\hline Medium & 30 \\
\hline Not at all & 5 \\
\hline Sporadic & 8 \\
\hline
\end{tabular}

TABLE 4: The role/purpose song-writing plays in the students' lives.

\begin{tabular}{|l|l|}
\hline CODE & TOTAL \\
\hline Intellectual & 10 \\
\hline Personal & 35 \\
\hline Expression (outwards) & 31 \\
\hline Not much & 11 \\
\hline Bands/performing & 7 \\
\hline Z - none & 1 \\
\hline Study & 8 \\
\hline
\end{tabular}

The role/purpose songwriting plays in their lives includes the expressing of something to others, fun, personal needs, writing for bands and for performance, writing for study at an institution, and an intellectual endeavour. The majority of responses indicate songwriting as playing a strong personal role, allowing them to give expression to their thoughts, emotions and ideas either to an audience or just for themselves (TABLE 4). Songwriting can be associated with one's "identity", "is how I connect to myself" and revitalises "self-beliefs". It is "self-satisfying", "therapeutic" and able "to make me feel better when I'm down"; an "outlet" for thoughts and feelings like "a diary"; and a "creative outlet." It is "fun," "relaxing" 
and pleasurable, allowing "expression of ideas and emotions" and enables feelings of altered "mind states". It "keeps me off the streets" and offers "stress relief". Songwriting can "act as a tool for communication", for example, being "spiritual, sharing religious truths and encouragement for church".

Responses indicate a majority of students are exploring their internal world in lyrics, however (TABLE 5) the boundary between those focused on one's internal world and other subjects was not clearly defined. Instead, students displayed a continuum from an exploration of lyrics which are deeply personal, through lyrics which are "an expression of my observation, internal and external", to lyrics which are more objectively about a situation. While $21 \%$ indicated that their lyrics explore a series of topics or subjects, few described an interest in writing about what Sting calls "news", public events. Lyrics with a deeply personal internal focus were described as "self-absorbed, emotions", however many students aimed to write lyrics which are "not restricted just to emotional situation[s]" but about "people and situations in my life", where "I put myself into someone else's shoes and become them and write about what's going on with them".

TABLE 5: How students characterise their song lyrics.

\begin{tabular}{|l|l|}
\hline CODE & TOTAL \\
\hline Exploration of one's internal world & 23 \\
\hline Exploration of a series of topics & 15 \\
\hline Both & 34 \\
\hline Others write the lyrics & 4 \\
\hline
\end{tabular}

Around $52 \%$ of responses indicated writing lyrics with a specific meaning in all or some songs, and 39\% for lyrics that are open to interpretation (TABLE 6). However, the "why?" at the end of the question, revealed reasons for adopting different lyric styles. Some were concerned with telling a story "because I find it hard to write words that don't follow a story line". Students wrote of deliberately wanting to deliver a clear "meaning so I can get through to people", and even "undercut the implied meaning through highlighting individual interpretation as the only true voice". By being "able to be taken quite literally" people can relate to them and can tell of the songwriter's personal experience "because at this point the songs are just for personal use".

Lyrics open to interpretation allow songs "to relate to a number of situations or topics". For several students there can be a deliberate use of metaphor and "deeper, sometimes hidden meaning needs to be disguised by abstract ambiguity" because "I know the personal meaning behind [the lyrics] but purposefully intend open interpretation." Many acknowledged "people create their own meanings for themselves". A small number of students were initially "not usually sure what the song means at first, but [...] try to find the meaning as I go". Others spoke of the craft of lyric writing, "enjoying figuring out meanings and words", "looking for rhymes" and sometimes using lyrics "for their sounds". 
TABLE 6: When writing songs, students aim for lyrics which have a specific meaning or lyrics which are open to interpretation.

\begin{tabular}{|l|l|}
\hline CODE & TOTAL \\
\hline Specific meaning & 52 \\
\hline Open to interpretation & 39 \\
\hline Storyline & 2 \\
\hline Clarity of message & 1 \\
\hline Wanting to change & 4 \\
\hline However they come & 2 \\
\hline
\end{tabular}

The question about inspiration deliberately focused respondents on two of the core aspects of songwriting, words and melody. Despite this, responses still touched on more ephemeral aspects of inspiration, which predominated in the words of professional songwriters. $44 \%$ of responses noted that the simultaneous occurrence of words and melody could be called inspiration; for around $15 \%$ it was not inspiration; and in $21 \%$ it might be (TABLE 7 ).

TABLE 7: If various elements occur simultaneously (that is, words and melody together), whether this an example of inspiration.

\begin{tabular}{|l|l|}
\hline CODE & TOTAL \\
\hline Yes & 32 \\
\hline No & 11 \\
\hline Personal & 5 \\
\hline Cognitive & 1 \\
\hline Don't know & 1 \\
\hline Maybe & 15 \\
\hline Facility & 1 \\
\hline Inspiration & 6 \\
\hline
\end{tabular}

For some, inspiration was characterised as a "concept", people, or "things that happen" which "comes before you have anything. It makes you want to compose and then what comes from that is the product of inspiration". Others found inspiration was embodied in their relationship with an instrument: "I am inspired while playing the piano". Other students used the metaphor of a "flow" to describe inspiration, using non-musical terms as "sub-conscious streaming [...] where I become immersed without distraction to the place within my subconscious so I just let it flow". Some described "subconscious" or a combination of flow and deliberate musical craft thinking about "certain vocabulary and vowel sounds [which] just fit together well with certain melodies" or perhaps "recognition of scale for melody, appropriate rhythm and words that fit". Two 
respondents wrote of believing inspiration sometimes to be "a touch of god" or "divine intervention?" but both with a touch of self-consciousness.

TABLE 8: How students characterize the balance of inspiration and craft in their song writing process.

\begin{tabular}{|l|l|}
\hline CODE & TOTAL \\
\hline Craft & 2 \\
\hline Inspiration & 10 \\
\hline More craft then inspiration & 16 \\
\hline More inspiration then craft & 26 \\
\hline Inspiration and craft & 12 \\
\hline Definition of inspiration & 1 \\
\hline Varies & 1 \\
\hline
\end{tabular}

Having responded to a question about the experience of inspiration, participants were then asked how they would characterize the balance of inspiration and craft in their songwriting process. The largest group (53\%) said there was more inspiration than craft in their songwriting, with many finding that "the early phase is more inspired and the late stages are all craft (albeit with an inspired goal in mind)" (TABLE 8). Responses noted the role of specific musical parameters in this balance: "inspiration to get [the] basic song, melody and chord structures [...and] craft used more to orchestrate and finer points of melodies" to "edit and make the song work a little more theoretically correct[ly]" and "to perfect and adjust the spontaneous stuff into more suitable structures". Others characterised the notion of craft as a negative force: "a good song can't exist without the inspiration that drives it. Craft just provides the transport and can often lead to irreversible rigidity".

Several responses revealed the role of increasing theoretical knowledge in songwriting, moving from an acknowledgement of the "need to improve my craft more because so far I have relied on inspiration and not been creating enough"; to "starting to learn how to use "crafting" to improve my song"; through to an understanding that "I'm inspired to work at the craft, and some results have inspired me to work further" even though "the craft is definitely more time consuming than the inspiration". Some responses noted, "inspiration comes naturally (craft is what comes with practice)" and "you can't get by on inspiration". With increased theoretical knowledge comes a change in the balance between inspiration and craft "because I understand the theory, whereas before everything had to be recorded, now I can write it down". For 26\% of students, craft played a larger role than inspiration in their song-writing; for $17 \%$ it was an equal balance; but for around $15 \%$, it was "100\% inspiration" because "ideas that arise from inspiration always seem to go further". For a few students, the influence and "stimulation" of "favourite" songwriters could be an inspiration, or provide a craft opportunity to "mimic what composers do".

Students were asked about their preferred order of songwriting process, with lyrics, melody and harmony, focused on in our songwriting teaching, as suggested 
parameters to consider. They were then asked why they prefer this order (TABLE 9). Twenty-three responses placed lyrics first, twenty-five placed lyrics last; twenty-five placed harmony first; thirty-five placed harmony last; nineteen placed melody first; and seven placed melody last. This indicates that melody is important but not necessarily the first consideration, with lyrics and harmony considered first by the majority of respondents. It was sometimes difficult to unpick whether there was a separation between melody and lyrics, because for some "lyrics and melody usually come first and always together." Of those who start with lyrics, reasons given were that "language is naturally melodic. Lyrics are just an accentuation of the feeling the tone in somebody's voice already implies" and because "lyrics are the most significant part of a song". This significance can be "because I feel that the lyrics guide me to choosing a good melody. My music has moods which are created from the lyrics" and from the mood and emotion of the lyrics, "the harmony can be judged [... - for example major/minor - and] the melody will flow off the harmony". The significance for others is because "the concept-idea of the song is established right at the beginning of the process", or because of the security of always having "the lyrics to set. [However] I have decided to change this order of process for my next song to see if I can be equally inspired". For one student, "the words seem to usually be sitting there waiting to be written down early in the morning", reflecting Nathan and Ben Folds' experience. Where they identified themselves, singers start with words and melody which "come easier than the music", and "I usually write songs to tell a story". Students who begin with a melody say "it seems easier to put the lyrics to music than the other way around" and one who "always [writes] lyrics last" felt that "the music comes more naturally to me."

The majority of responses that began with harmony, then move to the melody and onto the lyrics. Starting with harmony was often because songwriting begins while/through playing an instrument. For many, "my main voice is on the guitar, this is where the ideas are first conceived and developed. Once this is achieved I find that melody flows fairly easily from established vocals". This conceiving of ideas can be through an enjoyment of "grooving around with chord progressions. When I find one I like then comes the rest", because "I don't sing much, so a chord progression usually occurs first, then a melody follows". A similar process occurs through the keyboard. Here, harmony is leading melody formation, reflecting TABLE 9 responses although suggesting that melody and lyrics often emerge together.

In $19 \%$ of responses, there is a "need to start with a rhythm first", to start with "the riff (or hook)", or "start with an accompanying idea." For some, "direction, groove, texture and overall feel are more important [... with] lyrics and vocals [...] just another instrumental colour." A small number of students vary their approach perhaps deliberately because "it's different every time", or more intuitively: "I don't prefer one way over another." 
TABLE 9: Students' preferred order of song writing process: M (Melody); L (Lyrics); H (Harmony).

\begin{tabular}{|l|l|}
\hline CODE & TOTAL \\
\hline MLH & 13 \\
\hline LMH & 16 \\
\hline LMH or MLH & 6 \\
\hline LHM & 1 \\
\hline MHL & 6 \\
\hline HML & 19 \\
\hline HLM & 6 \\
\hline Groove driven & 12 \\
\hline Varies & 6 \\
\hline
\end{tabular}

Students were asked when they feel a song is complete and the majority response was "never" (TABLE 10). Reasons focused on the developmental importance of a changing song: "evolution is essential", even after it has been recorded, mixed, and rendered "to a polished finished audio file", to a questioning of whether a song is ever complete. Some responses said they don't "know enough theory to feel a song is complete". Around $14 \%$ of responses say performing a song indicates completion. This can be "when I can perform it with all intended instruments from start to finish", when a song has been performed to others and "they have enjoyed it as a finished work" or "when the final mix is done" in the studio. One student used to feel that performing a song indicated completion but now "when it's on paper" is the time.

TABLE 10: When do you feel a song is complete?

\begin{tabular}{|l|l|}
\hline CODES & TOTAL \\
\hline All musical issues addressed & 15 \\
\hline Never & 26 \\
\hline Performed & 11 \\
\hline Satisfied personally & 23 \\
\hline Hear it in my mind & 2 \\
\hline
\end{tabular}

For $30 \%$ of responses, completion is feeling personal satisfaction with a song as an individual or "when everyone in the group agrees it is satisfactory". "Feedback from others" is important and for others, "when you get sick of writing it". A small group feel a song is complete when "the song sticks in your head". From 19\% of responses, the compositional components of a song need to be all addressed to feel it is complete. For half of these students, a successful structure meant a song was complete, "so I am happy with how the sections fit together and flow into/out of each other". Students wrote holistically of specific musical parameters such as "when lyrics, melody, structure, harmony, drum and bass are in place", "when all 
lyrics and parts are done", and "when it has reached the desired climax of the theme".

The majority of responses (80\%) indicate continual editing and developing a song when it is complete (TABLE 11). For many students this editing and developing occurs through performing. There is a clear sense that when a song is "finished [it is] open to improvisation" because the "live version usually differs from original, more extended" and for many, avoids the boredom of playing a song "over and over". The role of the songwriter/performer's instrument is crucial whether as vocalist, "I may look over it after a while or find myself singing it differently"; instrumentalist, "different inversions of chords, make guitar part more interesting, subtle"; or working with a band, "usually it develops when I bring it to the band". Students wrote of continuing to change several musical parameters in the orchestration, instrumentation and adding "different articulation on certain notes, or dynamic building". The editing and developing can be small, occurring "only if I am recording or adjusting for live performance", or continuous rethinking due to either personal dissatisfaction or what could be called compulsive tinkering because "a song of my own is never complete". For others, the editing and developing occurs in the recording and mix down by "build[ing] up extra layers of instrumentation over the piano and melody" and because "a simple cut and paste can be undone easily and [allows] quick [...] checking [of] new ideas".

TABLE 11: Once a song is complete, whether students continue to edit and develop it.

\begin{tabular}{|l|l|}
\hline CODES & TOTAL \\
\hline Yes & 66 \\
\hline No & 16 \\
\hline
\end{tabular}

In a majority of responses (78\%), music theory knowledge assists songwriting process by "add[ing] to the tools available for song realisation" and "learning where the boundaries sit and why things do or don't fit" (TABLE 12). Many recognized the value of understanding the theory behind what they were writing noting "my growing knowledge has definitely expanded my process" and seeing it "as an investment that can be tapped into". There was often a growing familiarity in the use of learned theoretical knowledge with students incorporating "musical devices which I have learnt [...] into my work" and finding that "since studying it is much easier to start melodies and chord relation". In particular, several students wrote of the value of harmonic/chordal knowledge which "assists in having a problem solving method" and for some is liberating for their song-writing process with "the sky's the limit." Using theoretical knowledge can be a time-consuming process while for others it "save[s] time and increase[s] quality of the 'crafting' part". A small group wrote of the empowerment of theoretical knowledge: "before theory I was a dependent musician. Now I am able to do an entire piece by myself" with acknowledgement by some that "writing songs is harder if you don't know anything about music" because theory knowledge "gives alternatives". 
In $16 \%$ of responses, music theory knowledge restricts songwriting. Some prefer to use an instrument to write and for others theory knowledge is a restriction because of lack of facility and understanding. While some acknowledge this struggle to make the knowledge work for them others are proud of being "not strong in the theory department" and feel empowered "because I have no limitations or theory to what 'should' happen. It all comes from what I hear in my mind". For a few, the perceived restriction of theory is not "entirely a bad thing", for some, "it does nothing", and one is "still exploring and experimenting. Get back to me in around twenty-thirty years".

TABLE 12: How a student's level of music theory knowledge restricts, assists or empowers their process.

\begin{tabular}{|l|l|}
\hline CODES & TOTAL \\
\hline Neutral/nothing & 5 \\
\hline Assist & 52 \\
\hline Empower & 7 \\
\hline Restrict & 12 \\
\hline
\end{tabular}

Whether songwriting is geared to a particular market, and if so, how this impacts on their songwriting craft, revealed a continuum of thinking (TABLE 13) from those who do write in a particular style for a particular market; through those who would like to write for a particular market but at this stage, do not feel they have access to that market; those who write in the specific style they like (country, pop, rock); to students who write songs just for themselves. Of the $29 \%$ of responses which indicated that the student's song-writing is geared to a particular market, "mainstream", "hard rock", "pop", "folk", Christian songs, "the pop/rock market", "cult and underground or small market", "reggae" and "soul" were identified. Several students referred to a specific length of time, showing an understanding of "a certain time that's acceptable to most listeners (3'30" to $\left.4^{\prime} 20^{\prime \prime} \mathrm{min}\right)$ ".

TABLE 13: Whether a student's songwriting is geared to a particular market and how this impacts on their songwriting craft.

\begin{tabular}{|l|l|}
\hline CODES & TOTAL \\
\hline Yes & 22 \\
\hline No & 53 \\
\hline
\end{tabular}

As we coded the responses of students, we found the line between writing to a market and writing in a style you like yourself was often blurred. Broadly, students write for a market, "yes; a particular market? No. Minimally"; and more specifically, "I like writing country and ballad songs most. I write better songs by producing stuff that suits my taste in music". Another said "my style is funk/blues so it is appealing to a wide audience but I don't write songs with anyone or market in mind". Because responses like this indicated a less than deliberate focus 
on market, we coded them in the responses that they do not feel their song writing is geared to a particular market. Yet within this large group of students, others indicated an interest in eventually writing to a wide market or a focused market, "once I have a better handle on [song-writing] then yes I would be looking at new pop material and new jazz songs". Others indicated a change in thinking about their song-writing market: "at this point [do] not gear [...] to a particular market (not purposely)". However, for the largest group it is the case that "I just do it for myself".

Responses to both parts of the question indicate the impact or potential impact of market forces on their song-writing craft. When students write for a specific market, the impact on their song-writing can involve specific parameters. One student named musical aspects required for "rock, hard rock" songs "usually use scales most typically found in these styles as well as rhythms". Several commented on the impact of market on lyrics. One student, who identified as a Christian, recognised a need in songwriting "to change the way I think so the words can identify with everyone". For pop, "you need to write general lyrics," and for pop rock, "just make imagery simple. Not too many dark themes." One respondent named an age group and gave stylistic requirements.

TABLE 14: The importance of the role of an audience to a student's song-writing.

\begin{tabular}{|l|l|}
\hline CODES & TOTAL \\
\hline Peer feedback & 6 \\
\hline For self & 9 \\
\hline Not at all & 21 \\
\hline Not very & 11 \\
\hline Future consideration & 4 \\
\hline Considered & 39 \\
\hline
\end{tabular}

The affect of the audience on songwriting varied from future career directions, "increasingly important because I'd like to become financially self-supporting as a musician"; to an appreciation and enjoyment of "people enjoying my music [...] I feel more of a sharing of being human", coupled with an acknowledgement of the role of "ego" in this sharing. Around 36\% of responses felt that the role of an audience was not very or not at all important to their song-writing (TABLE 14). As with the previous question, we noted a continuum of thinking from a strong denial of the role of an audience, "it's more like a personal hobby", to a hope that someone else might like a song. Peers were regarded discretely from audiences, "[audience] not important. Peer feedback is more important". The majority of responses do consider their audience when song-writing (43\%): "If the audience does not connect or react, then the piece is most probably a failure". Some saw delineations in types of audiences: "I'd rather have a small loyal fanbase than a big bunch of just anybodys". There are those who plan to include audience feedback in their song-writing thinking in the future. 


\section{Conclusions}

The questions addressed five key areas drawn largely from the literature in relation to student songwriting presage: experience and compulsion; role of song lyrics; inspiration; craft and theory notation; audience and market. No student was entirely inexperienced in songwriting and over half had written a considerable body of song in the past. There was some correspondence in the percentages between those who had written over thirty songs and those who found songwriting a very compulsive activity.

It appeared to us, firstly, that student songwriters imbued value in an authenticity of personal experience as rendered in song form, and secondly, that they were attempting to transform life experiences into an expressive model with which they were familiar, often in order to express the experiences to others. Indeed, since the sixties many of the song-products of professional singersongwriters (presumably the models many of our students had in mind) have similarly been concerned with exploring universal themes via personal experience. In many popular songs, seemingly banal experiences are "transfigured both by the musical setting and the identification within the piece of the extraordinary in the ordinary and the universal in the local" (Mills 1994: 102). This over-arching ideology is expressed in the song-products of the professional songwriters referenced, and it appeared to guide the efforts of many of the student songwriters as well.

Although, in retrospect, some of our questions could have been more open, we found that while some student notions of inspiration reflected the spiritual often psychological/cognitive aspect of the professional songwriters, others were more grounded in their relationship with musical craft through instruments, words and pitch. Students wrote of inspiration, firstly, as a concept, person or situation that provided the impetus for writing a song, essentially what Harvey (1999) called "that" which provokes the creativity. Secondly, inspiration was the process itself, much like Czikszentmihalyi's (1990: 6) "flow [experience...] when consciousness is harmoniously ordered, and [people] want to pursue whatever they are doing for its own sake". The few students who ascribed their inspiration to a muse or saw themselves as being a receiver of songs did so with a degree of self-consciousness, in contrast to the professional songwriters cited who nominated a muse and/or a dreamlike or trance-like state as a conduit of inspiration without apparent selfconsciousness.

Whether students begin songwriting with melody, lyrics, harmony or rhythm, their consideration of how the song is actually composed may begin with inspiration but is then crafted for shape and refinement. As is the case for professional songwriters, for students instruments can provide an impetus to songwriting, with harmonic instruments often used initially to find harmonies, and vocalists beginning with melody and lyrics. Some professional songwriters feel they can continue the process through arranging and technology while for many students, the songwriting process continues through performing, where the written version comes alive off the page. Others keep tinkering with their songs and some use the recording and mix down to keep developing the song. For students, the writing process is complete when the song is performed, when all the 
compositional components are addressed, when feedback has been received from others, when the song stays with you. Although many professional songwriters are wary of theory rules, the majority of student songwriters valued this knowledge, some feeling empowered by it.

Several professional songwriters spoke of the balance between writing for a market and trusting one's own song-writing intuition. While students were less concerned about writing for a market, they knew which styles they liked and the market for that style, and many took into consideration the audience for their songs. This may be an intermediary step to embracing a wider variety of styles and therefore markets.

It was difficult mapping the levels of skills that students bring to the presage stage of songwriting instruction, onto Dreyfus's five-stage model of the human skill acquisition process. This was perhaps because of the deep personal identification with songwriting, and the level of creativity required. However, there were parallels, and within the five areas addressed in the student questionnaire, enough information emerged to suggest adaptation of the model in relation to previously acquired songwriting skills' levels brought to the presage stage (TABLE 15). This mapping also provides a useful summary of the results of the research.

The Novice begins with inspiration, a trigger for trying to write a complete song, without strong knowledge of the required "attributes". With the other stages comes understanding of lyrics, song structure, theory, audiences and markets, the components of the whole song, which the student seeks. This is a change in the order of Benner's three observable aspects of skilled performance, a move from an unachievable but familiar complete whole (based on past concrete experience as paradigms through songs of professional songwriters); the acquisition of relevant "abstract principles"; and finally the "involved" performer, more fully engaged in the situation. Inspiration is the compulsive catalyst for the songwriting.

Half of the students were in the first three stages of TABLE 15's model and half in Competency and Proficiency stages. The majority sought theory knowledge to improve and provide insights into their songwriting. Students, therefore, come to the tertiary classroom with a range of songwriting experiences, and this varied but often considerable knowledge-base needs to be understood by the teacher. As Folkestad (1998, in Folkestad 2006: 136) reminds us "when pupils come to [secondary] school they all possess a rich and in some ways sophisticated musical knowledge, acquired from a variety of outside-school musical activities". Lebler et al. (2009: 244) draw this thinking into life beyond institutional study, saying "if education is intended to prepare students for what awaits them [...] taking the previous learning experiences of students into account" can benefit the learning system. Instead of just focusing on authenticity of musics, Westerlund (2008: 92) argues, we should be concerned about "the authenticity of learning experiences and the learners' ability to see the relevance of their own learning and to have a sense of ownership of it". Presage knowledge is a start and helps build a more authentic learning environment. 
TABLE 15: Five-stage model for previously acquired skills' levels in presage student songwriters (Dreyfus 1982, adapted by Blom and Poole).

\begin{tabular}{|c|c|c|c|c|}
\hline NOVICE & $\begin{array}{l}\text { ADVANCED } \\
\text { BEGINNER }\end{array}$ & COMPETENCY & PROFICIENCY & EXPERTISE \\
\hline $\begin{array}{l}\text { Attempting } \\
\text { song-writing }\end{array}$ & Inspiration & $\begin{array}{l}\text { Inspiration \& } \\
\text { craft }\end{array}$ & $\begin{array}{l}\text { Inspiration \& } \\
\text { craft and } \\
\text { audience }\end{array}$ & $\begin{array}{l}\text { Inspiration, } \\
\text { craft, } \\
\text { audience and } \\
\text { market }\end{array}$ \\
\hline $\begin{array}{l}\text { Lyrics } \\
\text { focused on } \\
\text { self "self- } \\
\text { absorbed } \\
\text { emotions" }\end{array}$ & $\begin{array}{l}\text { Lyrics focused } \\
\text { on self "self- } \\
\text { absorbed } \\
\text { emotions" }\end{array}$ & $\begin{array}{l}\text { Lyrics open to } \\
\text { interpretation } \\
\text { beyond self }\end{array}$ & $\begin{array}{l}\text { Lyrics open to } \\
\text { interpretation } \\
\text { beyond self }\end{array}$ & $\begin{array}{l}\text { Lyrics open } \\
\text { to } \\
\text { interpretation } \\
\text { beyond self }\end{array}$ \\
\hline Inspiration & $\begin{array}{l}\text { Using more } \\
\text { inspiration } \\
\text { than } \\
\text { craft/theory }\end{array}$ & $\begin{array}{l}\text { Learning how } \\
\text { to craft "to } \\
\text { improve my } \\
\text { sound" }\end{array}$ & $\begin{array}{l}\text { Theory, } \\
\text { aural/inspiration }\end{array}$ & $\begin{array}{l}\text { Inspiration, } \\
\text { aural, theory; } \\
\text { sense of flow }\end{array}$ \\
\hline $\begin{array}{l}\text { "Don't know } \\
\text { enough } \\
\text { theory to feel } \\
\text { a song is } \\
\text { complete" }\end{array}$ & $\begin{array}{l}\text { Song never } \\
\text { complete - } \\
\text { "evolution is } \\
\text { essential" }\end{array}$ & $\begin{array}{l}\text { Performance } \\
\text { as vehicle for } \\
\text { continuing to } \\
\text { develop a song }\end{array}$ & $\begin{array}{l}\text { Performance } \\
\text { completes the } \\
\text { work }\end{array}$ & $\begin{array}{l}\text { Recording, } \\
\text { publication, } \\
\text { and public } \\
\text { reception }\end{array}$ \\
\hline $\begin{array}{l}\text { Lack of } \\
\text { music theory } \\
\text { knowledge }\end{array}$ & $\begin{array}{l}\text { Theory - "still } \\
\text { exploring and } \\
\text { experiencing } \\
\text { - get back to } \\
\text { me in around } \\
\text { twenty-thirty } \\
\text { years" }\end{array}$ & $\begin{array}{l}\text { Interested in } \\
\text { acquiring } \\
\text { theory } \\
\text { knowledge }\end{array}$ & $\begin{array}{l}\text { Theory used if } \\
\text { required and } \\
\text { known }\end{array}$ & $\begin{array}{l}\text { Theory used } \\
\text { if required } \\
\text { and known }\end{array}$ \\
\hline $\begin{array}{l}\text { No } \\
\text { audience, } \\
\text { market - } \\
\text { "just for } \\
\text { personal } \\
\text { use" }\end{array}$ & $\begin{array}{l}\text { No market; } \\
\text { for self with } \\
\text { some } \\
\text { awareness of } \\
\text { audience }\end{array}$ & $\begin{array}{l}\text { Audience } \\
\text { considered; } \\
\text { not the market }\end{array}$ & $\begin{array}{l}\text { Audience } \\
\text { considered; } \\
\text { awareness of } \\
\text { style }\end{array}$ & $\begin{array}{l}\text { Audience } \\
\text { and market } \\
\text { taken into } \\
\text { consideration }\end{array}$ \\
\hline
\end{tabular}




\section{References}

Barkley, E. F., Cross, K. P. and Major, C. H. 2005. Collaborative Learning Techniques. A Handbook for College Faculty. San Francisco: Jossey-Bass, A Wiley Imprint.

Barrett, M. 2005. Musical Communication and Children's Communities of Musical Practice. In D. Miell, R. MacDonald, D. J. Hargreaves Eds. Musical Communication. Oxford: Oxford University Press: 261-280.

Benner, P. 1984. From Novice to Expert. Excellence and Power in Clinical Nursing Practice. Menlo Park: Addison-Wesley.

Biggs. J.B. 1989. Approaches to the Enhancement of Tertiary Teaching. Higher Education Research \& Development 8 (1): 7-25.

Blume, J. 1999. 6 Steps to Songwriting Success. The Comprehensive Guide to Writing and Marketing Hit Songs. New York: Billboard Books.

Butler, J. 1996. Professional Development: Practice as Text, Reflection as Process, and Self as Locus. Australian Journal of Education, 40 (3): 265-283.

Campbell, P. S. -

1995. Of Garage Bands and Song-Getting: The Musical Development of Young

Rock Musicians. Research Studies in Music Education 4: 12-20.

1998. Songs in Their Heads. Music and Its Meaning in Children's Lives. New

York: OUP.

Carless, D. and Douglas, K. 2009. Songwriting and the Creation of Knowledge. In B.L. Bartleet and Carolyn Ellis Eds. Music Autoethnographies. Bowen Hills: Australian Academic Press: 23-38.

Citron, Stephen. 2000. A Complete Guide to the Craft of Song Writing. $7^{\text {th }}$ Edition. New York: Limelight Editions.

Csikszentmihalyi, M. 1990. Flow. The Psychology of Optimal Experience. New York: Harper Perennial.

Davis, S. -

1985. The Craft of Lyric Writing. Cincinnati: Writer's Digest Books.

1992. The Songwriters Idea Book. Cincinnati: Writer's Digest Books.

deGroot, A. 1965. Thought and Choice in Chess. The Hague: Mouton.

DeMain, B. 2004. In Their Own Words. Songwriters Talk About the Creative Process. Connecticut: Praeger.

Dreyfus, S. E. 1982. Formal Models vs. Human Situational Understanding: Inherent Limitations on the Modeling of Business expertise. Office: Technology and People, 1:133-165.

Dreyfus, S. E. and Dreyfus, H. L. 1980. A Five-Stage Model of the Mental Activities Involved in Directed Skill Acquisition. Unpublished report supported by the Air Force Office of Scientific Research (AFSC), USAF (Contract F49620-79-C0063), University of California at Berkeley, February.

Flanagan, B. -

1987. Written in my Soul. Conversations with Rock's Great Songwriters.

Chicago: Contemporary Books.

1990. Written in my Soul. Candid Interviews with Rock's Great Songwriters.

London/New York/Sydney: Omnibus Press. 
Folkestad, G. 2006. Formal and Informal Learning Situation or Practices vs Formal and Informal Ways of Learning. British Journal of Music Education, 23 (2): 135145.

Frith, S. 1987. Towards an Aesthetic of Popular Music. In R. Leppert and

S. McClary Eds. Music and Society. The Politics of Composition, Performance and Reception. Cambridge: Cambridge University Press: 133-149.

Gillette, S. 1995. Song Writing and the Creative Process. Pennsylvania: Sing Out! Green, L. 2001. How Popular Musicians Learn. Aldershot: Ashgate.

Hadley, S. 1996. A Rationale for the Use of Songs with Children Undergoing Bone Marrow Transplantation. The Australian Journal of Music Therapy 7: 1629.

Hannan, M. and Blom, D. 2012. The Role of Popular Songwriting in Three Australian Tertiary Music Curricula: Different Strokes for Different Folks? In J. Weller Ed. Educating Professional Musicians in a Global Context. Proceedings of the 19th International Seminar of the Commission for the Education of the Professional Musician (CEPROM) International Society for Music Education, Philippos Nakas Conservatory, Athens, Greece, 10-13 July 2012: 54-59. http://issuu.com/official_isme/docs/4_ceprom_2012_proceedings_web?viewMo de=magazine $\&$ mode=embed. Accessed: 8 March. 2014.

Harvey, J. 1999. Music and Inspiration. M. Downes Ed. London: Faber and Faber.

Hoskyns, B. 2005. Hotel California. Singer-Songwriters and Cocaine Cowboys in the LA Canyons, 1967-1976. London: Harper Perennial.

Josefs, J. 1996. Writing Music for Hit Songs. $2^{\text {nd }}$ Edition. New York: Schirmer Trade Books.

Kaschub, M. 1997. A Comparison of Two Composer-Guided Large Group Composition Projects. Research Studies in Music Education 8: 15-28.

Keil, C. 1985. People's Music Comparatively: Style and Stereotype, Class and Hegemony. Dialectical Anthropology 10: 119-130.

Kennedy, M. 2004. Opening the Doors to Creativity: A Pre-Service Teacher Experiment. Research Studies in Music Education 23: 32-41

Kruger, D. 2005. Songwriters Speak: Conversations about Creating Music. Sydney: Limelight Press.

Kuhn, T. 1970. The Structure of Scientific Revolutions. $2^{\text {nd }}$ edition. Chicago: University of Chicago Press.

Lebler, D., Burt-Perkins, R., and Carey, G. 2009. What the Students Bring: Examining the Attributes of Commencing Conservatoire Students, International Journal of Music Education 27 (3): 232-249.

LeCompte, M. G. and Preissle, J. 1993. Ethnography and Qualitative Design in Educational Research. $2^{\text {nd }}$ edition. San Diego: Academic Press.

Lethem, J. 2006. The Genius of Bob Dylan. Rolling Stone 658, November: 44-51. Lilliestam, L. 1996. On Playing by Ear. Popular Music 15 (2): 195-216.

Lowman, R. 2001. A Vega Sense of Unease. The Sydney Morning Herald, October: 13-14: Metropolitan 4.

Macquarie, Australia's National Dictionary - Essential Dictionary. 1999. Sydney: The Macquarie Library Pty. Ltd.

McGillen, C.W. 2004. In Conversation with Sarah and Matt: Perspectives on Creating and Performing Original Music. British Journal of Music Education 21 (3): 279-293. 
McGillen, C. and Mcmillan, R. -

2003. Cooperative Song Writing: Adventures in Anarchy and Engagement with Adolescents. Australian Journal of Music Education 1: 25-38.

2005. Engaging with Adolescent Musicians: Lessons in Song Writing, Cooperation and the Power of Original Music. Research Studies in Music Education 25: 36-54.

Mills, P. 1994. Into the Mystic: The Aural Poetry of Van Morrison. Popular Music 13 (1): 91-103.

O'Callaghan, C. 2004. Identifying Comparable Therapeutic Foundations Between "musical replay" and improvisation. Cancer Research Inspires a Hybrid Perspective. Nordic Journal of Music Therapy 13 (2): 127-142.

Partti, H. and Westerlund, H. 2013. Envisioning Collaborative Composing in Music Education: Learning and Negotiation of Meaning in Operabyyou.com. British Journal of Music Education 30 (2): 207-222.

Pattison, P. 1995. Writing Better Lyrics. Cincinnati: Writer's Digest Books.

Potter, J. 1994. The Singer, Not the Song: Women Singers as Composer-Poets. Popular Music, 13 (2): 191-199.

Shepherd, J. 1982. A Theoretical Model for the Sociomusicological Analysis of Popular Musics. Popular Music 2: 145-177.

Söderman, J. and Folkestad, G. 2004. How Hip-Hop Musicians Learn: Strategies in Informal Creative Music Making. Music Education Research 6 (3): 313-326.

Sudnow, D. 2001. Ways of the Hand. A Rewritten Account. Revised Edition. Cambridge, Massachusetts: The MIT Press.

Unknown author [probably Moore, A.]. 2004. Principles for Teaching and Assessing Songwriting in Higher Education.

http://www.heacademy.ac.uk/assets/documents/subjects/palatine/UKSongwriting-Festival-principles-for-teaching-and-assessing-song-writing.pdf. Accessed: 10 May, 2014.

Webb, J. 1998. Tunesmith: Inside the Art of Songwriting. New York: Hyperion.

West, A. n.d. Creating an MA in Songwriting. Bath Spa University. http://www.heacademy.ac.uk/assets/documents/subjects/palatine/developingpedagogical-tools-creating-an-ma-in-songwriting.pdf. Accessed: 10 May, 2014. Westerlund, H. 2008. Justifying Music Education: A View from Here-and-Now Value Experience. Philosophy of Music Education Review 16 (1): 79-95. Zollo, P. 1997. Songwriters on Songwriting. New York: Da Capo Press. 